\title{
Helicobacter Pylori is the Cause of Gastric Cancer
}

\author{
Ilija Barukčićc \\ ${ }^{1}$ Internist, Horandstrasse, DE-26441 Jever, Germany \\ Correspondence: Ilija Barukčić, Horandstrasse, DE-26441 Jever, Germany. Tel: 49-4466-333. E-mail: \\ Barukcic@t-online.de
}

Received: May 21, 2018; Accepted: June 13, 2018; Published: June 22, 2018

\begin{abstract}
Objective: This study presents a systematic meta-analysis of the relationship between Helicobacter pylori (HP) infection and gastric cancer (GC).
\end{abstract}

Materials and Methods: Twelve articles including 21589 subjects were selected (1237 cases and 20352 controls). These data were analyzed using the mathematical formula of the conditio sine qua non relationship and the causal relationship formula.

Results: The data re-analyzed support the Null hypothesis without a Helicobacter pylori infection no human gastric cancer. The causal relationship between HP and GC is highly significant.

Conclusion: Helicobacter pylori is the cause of human gastric cancer.

Keywords: Helicobacter pylori, gastric cancer, cause effect relationship, causality

\section{Introduction}

Gastric cancer mortality and incidence decreased substantially over the last decades in most countries worldwide. Still, gastric cancer (GC) is among the most common causes of cancer death globally (Ferro et al., 2014) and the second leading cause of cancer-related mortality worldwide. Early modern humans migrated (Correa \& Piazuelo, 2012) out of Africa along with the bacterium Helicobacter pylori, its own oldest and closest companion, approximately 60,000 years ago. Meanwhile, H. pylori infection affects about $50 \%$ of the global (Tobacco Smoke and Involuntary Smoking. 2004) population. German scientists (Blaser, 2005) identified spiral-shaped bacteria in the human stomach in 1875. Bizzozero (Bizzozero, 1893) an Italian pathologist, described similarly shaped bacteria in the stomach of dogs in 1893. H. pylori is a spiral-shaped, gram-negative microaerophilic bacterium which has been re-discovered (Buzás, 2004) by Barry J. Marshall and J. Robert Warren (Warren \& Marshall, 1983) in 1983. The first description of gastric ulceration (Buckley \& O'Morain, 1998) was reported in 1586 by an Italian physician (Donati, 1586). For a long time, the therapy of gastric ulceration was dominated by the 1910 dictum 'no acid, no ulcer' (Schwarz, 1910) of the Croatian physician Karl Schwarz. In particular, several studies (Forman et al., 1991; Nomura et al., 1991; Parsonnet et al., 1991; Estevens et al., 1993) reported a higher risk of the development of gastric cancer in subjects with positive serologic tests for H. pylori. Finally, the World Health Organization and the International Agency for Research on Cancer (IARC Working Group on the Evaluation of Carcinogenic Risks to Humans. 1994) classified H pylori as a class 1 carcinogen in 1994. The rates of Helicobacter pylori infection in patients with gastric cancer vary greatly among studies. Thus far, most but not all studies, systematic reviews and meta-analysis confirmed (Lin et al., 1995) that H. pylori is associated with gastric cancer. However, due to conflicting reports (Moss, 2017) in the literature regarding the relationship between H. pylori and human gastric cancer Helicobacter pylori is still not accepted as the cause of gastric cancer (Barukčić, 2005; Barukčić, 2006; Barukčić, 2006; Barukčić, 2009; Barukčić, 2017; Ando et al., 2006).

\section{Material and Methods}

The rates of Helicobacter pylori infection vary greatly among studies. These variations are attributable to differences in the methods of detecting H. pylori (enzyme-linked immunosorbent assay (ELISA), western blot et cetera) which are associated with different false negative results or with the definition of cut of values and other factors.

\subsection{Search Strategy}

For the questions addressed in this paper, Pubmed was searched for appropriate studies conducted in any country which investigated the relationship between Helicobacter pylori and gastric cancer. 
The search in Pubmed was performed while using medical key words like "Helicobacter pylori" and "gastric cancer" and "antibody" and "review" et cetera. The articles found where saved as a *txt file while using Pubmed support (Menu: Send to, Choose Radio Button: File, Choose Format: Abstract (text). Click buttom "create file"). The created *.txt file was converted into a *.pdf file. The abstracts where studied within the *.pdf file.

Those articles were considered for a review which provided access to data without any data access barrier; no data access restrictions were accepted. Additionally, references from relevant publications and review articles were checked. Studies were included if the same allowed to compare the prevalence of Helicobacter pylori in patients with gastric cancer with the prevalence in healthy controls.

Studies were excluded if insufficient data were provided to calculate the measures of relationship or if there were data access barriers.

\subsection{The Data of the Studies Analyzed}

The data of the studies analyzed are presented by the table 1 (Table 1). In point of fact, bias due to the differences in the methods used to detect HP and a systemic and substantial under-detection of Helicobacter pylori infection and underestimation of its effect on gastric cancer is at the end not excluded.

Table 1. The data of the studies considered for a meta-analysis

\begin{tabular}{llllllll}
\hline Study Id & Year & Country & N & Case Pos & Case Tot & Contol pos & Control Tot \\
\hline Forman et al. (Forman et al., 1991) & 1991 & UK & 145 & 20 & $\mathbf{2 9}$ & 54 & $\mathbf{1 1 6}$ \\
Parsonnet et al. (Nomura et al., 1991) & 1991 & USA & 295 & 92 & $\mathbf{1 0 9}$ & 111 & $\mathbf{1 8 6}$ \\
Nomura et al. (Parsonnet et al., 1991) & 1991 & USA & 218 & 103 & $\mathbf{1 0 9}$ & 83 & $\mathbf{1 0 9}$ \\
Uemura et al. (Uemura et al., 2001) & 2001 & Japan & 1526 & 36 & $\mathbf{3 6}$ & 1210 & $\mathbf{1 4 9 0}$ \\
Miki (Miki 2011) & 2011 & Japan & 5290 & 59 & $\mathbf{6 3}$ & 4151 & $\mathbf{5 2 2 7}$ \\
González et al. (González et al., 2012) & 2012 & Spain & 476 & 72 & $\mathbf{8 8}$ & 188 & $\mathbf{3 8 8}$ \\
Keck et al. (Keck et al., 2014) & 2014 & USA & 468 & 112 & $\mathbf{1 2 2}$ & 285 & $\mathbf{3 4 6}$ \\
Yoshida et al. (Yoshida et al., 2014) & 2014 & Japan & 4655 & 81 & $\mathbf{8 7}$ & 3576 & $\mathbf{4 5 6 8}$ \\
Sarker et al. (Sarker et al., 2017) & 2017 & Bangladesh & 634 & 99 & $\mathbf{1 1 4}$ & 351 & $\mathbf{5 2 0}$ \\
Huerta et al. (Huerta et al., 2017) & 2017 & Spain & 2277 & 239 & $\mathbf{2 5 7}$ & 1777 & $\mathbf{2 0 2 0}$ \\
Fernández de Larrea-Baz et al. & & & & & & & \\
(Fernández et al., 2017) & 2017 & Spain & 2284 & 202 & $\mathbf{2 1 3}$ & 1822 & $\mathbf{2 0 7 1}$ \\
Shuto et al. (Shuto et al., 2017) & 2017 & Japan & 3321 & 10 & $\mathbf{1 0}$ & 1881 & $\mathbf{3 3 1 1}$ \\
\hline
\end{tabular}

Table 2. The sample space of a contingency table

\begin{tabular}{|c|c|c|c|c|}
\hline \multirow{5}{*}{$\begin{array}{l}\text { Condition } A_{t} \\
\text { (HP PCR DNA) }\end{array}$} & \multirow{5}{*}{$\begin{array}{l}\text { Yes }=+1 \\
\text { Not }=+0 \\
\text { Total }\end{array}$} & \multicolumn{3}{|c|}{$\begin{array}{l}\text { Conditioned } \mathrm{B}_{\mathrm{t}} \\
\text { (Crohn's disease) }\end{array}$} \\
\hline & & $Y e s=+1$ & Not $=+0$ & Total \\
\hline & & $\mathbf{a}_{\mathrm{t}}$ & $\mathbf{b}_{\mathrm{t}}$ & $\mathrm{A}_{\mathrm{t}}$ \\
\hline & & $\mathbf{c}_{\mathrm{t}}$ & $\mathbf{d}_{\mathrm{t}}$ & $\underline{\mathbf{A}}_{\mathrm{t}}$ \\
\hline & & $B_{t}$ & $\underline{\boldsymbol{B}}_{t}$ & $N_{\mathrm{t}}$ \\
\hline
\end{tabular}

\subsection{Statistical Analysis}

All statistical analyses were performed with Microsoft Excel ® version 14.0.7166.5000 (32-Bit) software (Microsoft GmbH, Munich, Germany). All P values are two-sided; significance was indicated by a P value of less than 0.05 . The following statistical tools and techniques were used to analyze the data.

\subsubsection{The $2 \times 2$ Table}

The 2x2 table in this article is defined (Barukčić, 2005; Barukčić, 2006; Barukčić, 2006; Barukčić, 2009; Barukčić, 2017), (Barukčić, 1989; Barukčić, 1997) in general more precisely (Table 2) as follows.

In general it is $(a+b)=A_{t},(c+d)=\underline{A}_{t},(a+c)=B_{t},(b+d)=\underline{B}_{t}$ and $a_{t}+b_{t}+c_{t}+d_{t}=N_{t}$. Equally, it is $B_{t}+\underline{B}_{t}=A_{t}+\underline{A}_{t}=N_{t}$. In this context, it is $p\left(a_{t}\right)=p\left(A_{t} \cap B_{t}\right), p\left(A_{t}\right)=p\left(a_{t}\right)+p\left(b_{t}\right)$ or in other words $p\left(A_{t}\right)=p\left(A_{t} \cap B_{t}\right)+p\left(A_{t} \cap \underline{B}_{t}\right)$ while $p\left(A_{t}\right)$ is not defined as $p\left(a_{t}\right)$. In the same context, it should be considered that $p\left(B_{t}\right)=p\left(a_{t}\right)+p\left(c_{t}\right)=p\left(A_{t} \cap B_{t}\right)+p\left(c_{t}\right)$ and 
equally that $p\left(\underline{B}_{t}\right)=1-p\left(B_{t}\right)=p\left(b_{t}\right)+p\left(d_{t}\right)$. In point of fact, the joint probability of $A_{t}$ and $B_{t}$ is denoted by $p\left(A_{t} \cap B_{t}\right)$. It is $p\left(a_{t}\right)+p\left(c_{t}\right)+p\left(b_{t}\right)+p\left(d_{t}\right)=1$. These relationships are viewed by the table (Table 3 ) as follows.

Table 3. The probabilities of a contingency table

\begin{tabular}{|c|c|c|c|c|}
\hline \multirow{5}{*}{$\begin{array}{c}\text { Condition } \\
A_{t}\end{array}$} & \multirow{5}{*}{$\begin{array}{l}\text { Yes }=+1 \\
\text { No }=+0 \\
\text { Total }\end{array}$} & \multicolumn{3}{|l|}{$\begin{array}{l}\text { Conditioned } \\
\mathrm{B}_{\mathrm{t}}\end{array}$} \\
\hline & & $Y e s=+1$ & $\mathrm{No}=+0$ & Total \\
\hline & & $\mathbf{p}\left(\mathbf{a}_{\mathbf{t}}\right)=\mathbf{p}\left(\mathbf{A}_{t} \cap \mathbf{B}_{t}\right)$ & $\mathbf{p}\left(\mathbf{b}_{\mathbf{t}}\right)$ & $\mathbf{p}\left(\mathbf{A}_{\mathbf{t}}\right)$ \\
\hline & & $\mathbf{p}\left(\mathbf{c}_{\mathrm{t}}\right)$ & $p\left(d_{t}\right)$ & $\mathbf{p}\left(\underline{\mathbf{A}_{\mathrm{t}}}\right)$ \\
\hline & & $p\left(B_{t}\right)$ & $p\left(\underline{B}_{t}\right)$ & 1 \\
\hline
\end{tabular}

\subsubsection{Independence}

In the case of independence of $A_{t}$ and $B_{t}$ it is

$$
\mathrm{p}\left(\mathrm{A}_{\mathrm{t}} \cap \mathrm{B}_{\mathrm{t}}\right) \equiv \mathrm{p}\left(\mathrm{A}_{\mathrm{t}}\right) \times \mathrm{p}\left(\mathrm{B}_{\mathrm{t}}\right)
$$

\subsubsection{Necessary Condition (Conditio Sine Qua Non)}

The formula of the necessary condition (conditio sine qua non) (Barukčić, 2005; Barukčić, 2006; Barukčić, 2006; Barukčić, 2009; Barukčić, 2017), (Barukčić, 1989; Barukčić, 1997) relationship was derived as

$$
\mathrm{p}\left(\mathrm{A}_{\mathrm{t}} \leftarrow \mathrm{B}_{\mathrm{t}}\right) \equiv \mathrm{p}\left(\mathrm{A}_{\mathrm{t}} \cap \mathrm{B}_{\mathrm{t}}\right)+\left(1-\mathrm{p}\left(\mathrm{B}_{\mathrm{t}}\right)\right) \equiv \frac{\mathrm{a}_{\mathrm{t}}+\mathrm{b}_{\mathrm{t}}+\mathrm{d}_{\mathrm{t}}}{\mathrm{N}} \equiv+1
$$

and used to proof the hypothesis: without $\mathrm{A}_{\mathrm{t}}$ (i.e. condition, "risk factor") no $\mathrm{B}_{\mathrm{t}}$ (i. e. conditioned, outcome).

\subsubsection{The $\mathrm{X}^{2}$ Goodness of Fit Test of a Necessary Condition}

Under conditions where the chi-square (Pearson, 1900) goodness of fit test cannot be used it is possible to use an approximate and conservative (one sided) confidence interval as discussed by Rumke (Rumke, 1975), Louis (Louis, 1981), Hanley et al. (Hanley \& Lippman-Hand, 1983) and Jovanovic (Jovanovic \& Levy, 1997) known as the rule of three. According to the definition of the conditio sine qua non relationship it is

$$
\mathrm{p}\left(\mathrm{A}_{\mathrm{t}} \cap \mathrm{B}_{\mathrm{t}}\right)+\left(1-\mathrm{p}\left(\mathrm{B}_{\mathrm{t}}\right)\right) \equiv+1
$$

or

$$
\mathrm{p}\left(\mathrm{A}_{\mathrm{t}} \cap \mathrm{B}_{\mathrm{t}}\right)+1-\mathrm{p}\left(\mathrm{B}_{\mathrm{t}}\right) \equiv+1
$$

or

$$
\mathrm{p}\left(\mathrm{A}_{\mathrm{t}} \cap \mathrm{B}_{\mathrm{t}}\right)-\mathrm{p}\left(\mathrm{B}_{\mathrm{t}}\right) \equiv 0
$$

Multiplying equation before by the population or sample size $\mathrm{N}$, it is

$$
\mathrm{N} \times \mathrm{p}\left(\mathrm{A}_{\mathrm{t}} \cap \mathrm{B}_{\mathrm{t}}\right) \equiv \mathrm{N} \times \mathrm{p}\left(\mathrm{B}_{\mathrm{t}}\right)
$$

or

$$
\mathrm{N} \times \mathrm{p}\left(\mathrm{A}_{\mathrm{t}} \cap \mathrm{B}_{\mathrm{t}}\right)-\mathrm{N} \times \mathrm{p}\left(\mathrm{B}_{\mathrm{t}}\right)=0
$$

The square operation yields

$$
\left(\mathrm{N} \times \mathrm{p}\left(\mathrm{A}_{\mathrm{t}} \cap \mathrm{B}_{\mathrm{t}}\right)-\mathrm{N} \times \mathrm{p}\left(\mathrm{B}_{\mathrm{t}}\right)\right) \times\left(\mathrm{N} \times \mathrm{p}\left(\mathrm{A}_{\mathrm{t}} \cap \mathrm{B}_{\mathrm{t}}\right)-\mathrm{N} \times \mathrm{p}\left(\mathrm{B}_{\mathrm{t}}\right)\right)=0 \times 0
$$

Dividing by $\mathrm{N} \times \mathrm{p}\left(\mathrm{B}_{\mathrm{t}}\right)$ we obtain

$$
\frac{\left(N \times p\left(A_{t} \cap B_{t}\right)-N \times p\left(B_{t}\right)\right)^{2}}{N \times p\left(B_{t}\right)}=0
$$


which is equivalent with

$$
\frac{\left(a_{t}-\left(B_{t}\right)\right)^{2}}{\left(B_{t}\right)}=\frac{\left(a_{t}-\left(a_{t}+c_{t}\right)\right)^{2}}{\left(B_{t}\right)}=\frac{\left(c_{t}\right)^{2}}{\left(B_{t}\right)}=0
$$

Adding 0 yields

$$
\frac{\left(c_{t}\right)^{2}}{\left(B_{t}\right)}+0=0+0
$$

Using the continuity correction, the chi-square value of a conditio sine qua non distribution follows as

$$
\chi^{2}(\mathrm{SINE}) \equiv \frac{\left(\mathrm{c}_{\mathrm{t}}-\left(\frac{1}{2}\right)\right)^{2}}{\left(\mathrm{~B}_{\mathrm{t}}\right)}+0=0
$$

This definition of the $\mathrm{X}^{2}$ distribution of a conditio sine qua non distribution (degrees of freedom $=2-1=1$ ) is more precise than already published (Barukčić, 2018; Barukčić, 2018; Barukčić, 2018) formulas. The use of the continuity correction should follow the rules of statistics as established and valid today. In this context, it is not necessary to improve the definition of the $\mathrm{X}^{2}$ distribution of a conditio per quam distribution as already published (Barukčić, 2018; Barukčić, 2018; Barukčić, 2018).

\subsubsection{The Mathematical Formula of the Causal Relationship k}

The mathematical formula of the causal relationship k (Barukčić, 2005; Barukčić, 2006; Barukčić, 2006; Barukčić, 2009; Barukčić, 2017), (Barukčić, 1989; Barukčić, 1997) is defined at every single event, at every single Bernoulli trial $t$, as

$$
\mathrm{k}\left({ }_{\mathrm{R}} \mathrm{U}_{\mathrm{t}},{ }_{0} \mathrm{~W}_{\mathrm{t}}\right) \equiv \frac{\left(\mathrm{p}\left({ }_{\mathrm{R}} \mathrm{U}_{\mathrm{t}} \times{ }_{0} \mathrm{~W}_{\mathrm{t}}\right)-\left(\mathrm{p}\left({ }_{\mathrm{R}} \mathrm{U}_{\mathrm{t}}\right) \times \mathrm{p}\left({ }_{0} \mathrm{~W}_{\mathrm{t}}\right)\right)\right)}{\sqrt[2]{\left(\mathrm{p}\left({ }_{\mathrm{R}} \mathrm{U}_{\mathrm{t}}\right) \times \mathrm{p}\left({ }_{\mathrm{R}} \underline{\mathrm{U}}_{\mathrm{t}}\right)\right) \times\left(\mathrm{p}\left({ }_{0} \mathrm{~W}\right) \times \mathrm{p}\left({ }_{0} \underline{\mathrm{W}}_{\mathrm{t}}\right)\right)}}
$$

where ${ }_{\mathrm{R}} \mathrm{U}_{\mathrm{t}}$ denotes the cause and ${ }_{0} \mathrm{~W}_{\mathrm{t}}$ denotes the effect while the chi-square distribution (Pearson, 1900) can be applied to determine the significance of causal relationship k. Correlation is not causation, causation is not correlation. The relationship between correlation and causation is discussed already in many publications (Pearson, 1900). This does not necessarily imply that repeating itself over and over again may contribute anything new to further scientific progress.

Table 4. The critical values of the chi square distribution (degrees of freedom: 1)

\begin{tabular}{llll}
\hline & p-Value & One sided X $^{\mathbf{2}}$ & Two sided X $^{\mathbf{2}}$ \\
\hline & 0,1000000000 & 1,642374415 & 2,705543454 \\
& $\mathbf{0 , 0 5 0 0 0 0 0 0 0 0}$ & $\mathbf{2 , 7 0 5 5 4 3 4 5 4}$ & $\mathbf{3 , 8 4 1 4 5 8 8 2 1}$ \\
& 0,0400000000 & 3,06490172 & 4,217884588 \\
& 0,0300000000 & 3,537384596 & 4,709292247 \\
The chi & 0,0200000000 & 4,217884588 & 5,411894431 \\
square & 0,0100000000 & 5,411894431 & 6,634896601 \\
distribution & 0,0010000000 & 9,549535706 & 10,82756617 \\
& 0,0001000000 & 13,83108362 & 15,13670523 \\
& 0,0000100000 & 18,18929348 & 19,51142096 \\
& 0,0000010000 & 22,59504266 & 23,92812698 \\
& 0,0000001000 & 27,03311129 & 28,37398736 \\
& 0,0000000100 & 31,49455797 & 32,84125335 \\
& 0,0000000010 & 35,97368894 & 37,32489311 \\
& 0,0000000001 & 40,46665791 & 41,82145620 \\
\hline
\end{tabular}




\subsubsection{The Chi Square Distribution}

Evaluating hypotheses in the light of empirical facts is not an easy task. In particular, mathematics and statistics provide us with specific methods to relate facts and hypotheses under certain conditions. And there is so much more. Interested readers may bear in mind that an entirely different approach and one very important aspect of statistics is the conceptual analysis of causal relations too. A general discussion of the justification of inferences or procedures which extrapolate from data to predictions and general facts may be found in secondary literature. In this context, the chi-squared distribution (Pearson, 1900), a widely known distribution in hypothesis testing, in inferential statistics or in construction of confidence intervals, is of use. It can be insightful to consider the following critical values of the chi square distribution as visualized by Table 4 .

\section{Results}

\subsection{Helicobacter Pylori Infection is the Cause of Human Gastric Cancer}

\section{Claims.}

\section{Null hypothesis:}

A Helicobacter pylori infection is a necessary condition (a conditio sine qua non) of human gastric cancer. In other words, the sample distribution of the study analyzed agrees with the hypothetical (theoretical) distribution of a necessary condition.

Table 5. Without Helicobacter pylori infection no gastric cancer

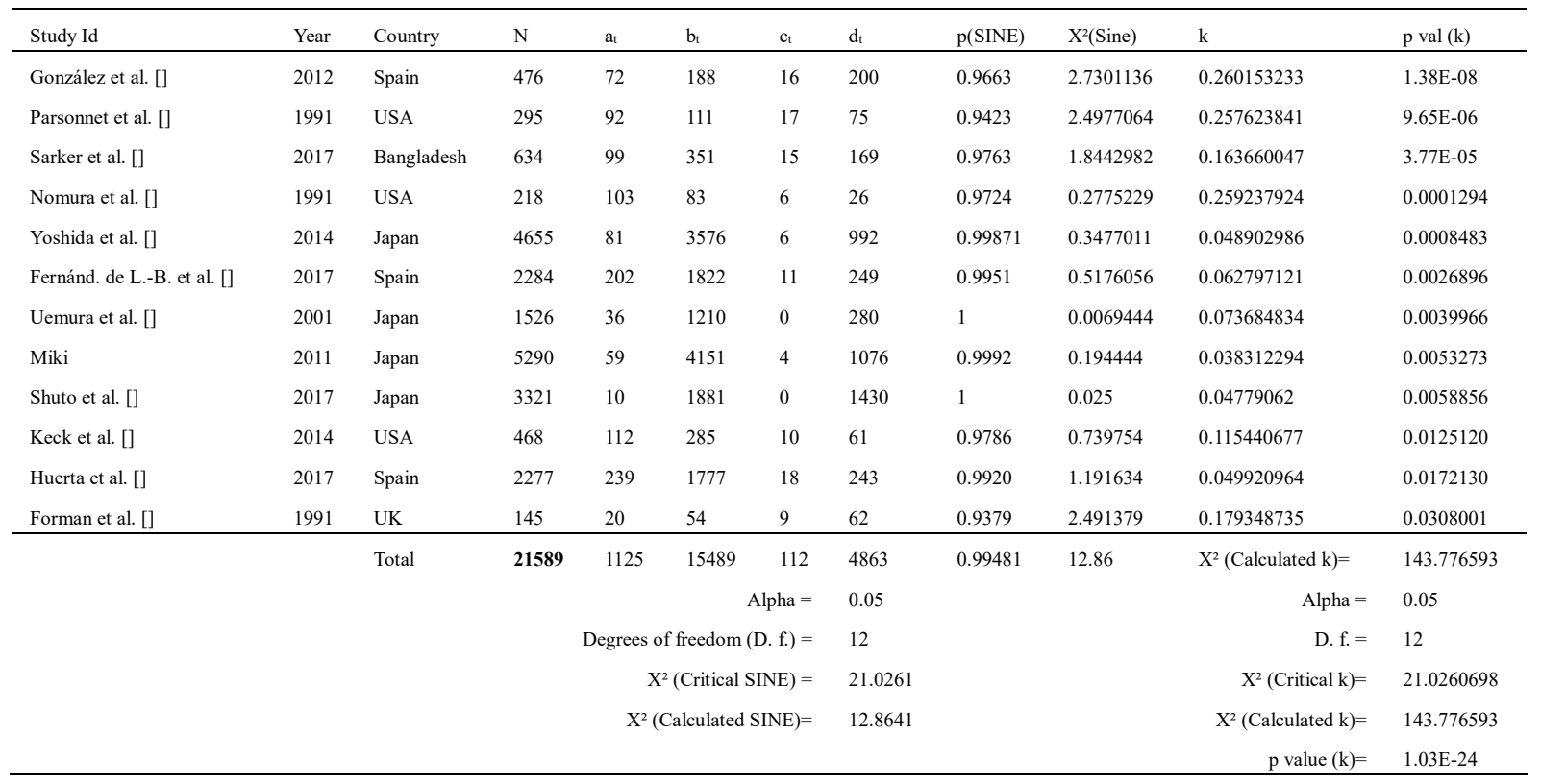

\section{Alternative hypothesis:}

A Helicobacter pylori infection is not a necessary condition (a conditio sine qua non) of human gastric cancer. In other words, the sample distribution of the study analyzed does not agree with the hypothetical (theoretical) distribution of a necessary condition.

The significance level (Alpha) below which the null hypothesis will be rejected is alpha=0,05.

\section{Proof.}

The results of the re-analyses of the data reviewed by this article (Table 1) which investigated the relationship between Helicobacter pylori and gastric cancer are viewed by the table (Table 5). Altogether, 12 studies were metaanalyzed while the level of significance was alpha $=0,05$. In toto, 12 from 12 studies provide significant evidence of a conditio sine qua non relationship between Helicobacter pylori and gastric cancer. The sample size was $\mathrm{N}=$ 21589 while the conditio sine qua non probability/relative frequency of the studies analyzed was (21589-112)/ $21589=0.99481$. In other words, the data analyzed support the hypothesis without a Helicobacter pylori infection no human gastric cancer. In the same respect, 12/12 studies analyzed provided evidence of a significant or highly 
significant cause effect relationship between Helicobacter pylori and human gastric cancer. In point of fact, since without a Helicobacter pylori infection human gastric cancer will not develop we authorized to draw the following conclusion. Helicobacter pylori is the cause of human gastric cancer $(\mathrm{k} \sim+0,081607078$, $\mathrm{p}$-value $=1,03 \mathrm{E}-24)$. Q. e. d.

\section{Discussion}

Since the re-discovery of Helicobacter pylori the possibility of a relationship with gastric cancer has been tested but still not supposedly proven. Numerous different studies of various designs from many countries around the world and several meta-analyses (Huang et al., 1998; Rokkas, Rokka \& Portincasa, 2017) have been published looking at the relationship between $\mathrm{H}$ pylori infection and gastric cancer. Over the years, studies have produced conflicting results. Gastric cancer remains a major scientific, medical and public health challenge. The exact mechanisms by which $\mathrm{H}$ pylori might cause gastric cancer is still under investigation and remains to be discovered. $\mathrm{H}$. pylori infection varies among regions but besides of all there is emerging evidence that $\mathrm{H}$. pylori is able to raise the risk of gastric cancer. Thus far, the findings of this study are consistent with those of several previous studies and metaanalysis. The prevalence of $\operatorname{IgG}$ antibodies to $\mathrm{H}$ pylori in blood samples of cases and controls is one way to proof the relationship between gastric cancer and helicobacter pylori. The presence of $\mathrm{H}$ pylori antibodies does not guarantee the presence of $\mathrm{H}$. pylori inside the stomach and is a potential sources of human, systematic and random error and bias and can cause the results of a research study to be incorrect. The set of study or experimental data is seldom perfect and complete which may threat the validity of the study. In general, researchers even if aware of the bias as associated with study design and the data the amount of studies which are reporting the same result is difficult to be ignored. Without a Helicobacter pylori infection no human gastric cancer $(\mathrm{N}=21589, \mathrm{p}(\mathrm{SINE})=0.99481$, $\mathrm{X}^{2}($ Calculated SINE $)=12,86<\mathrm{X}^{2}($ Critical SINE $)=21,0261, \mathrm{p}$ value $\left.(\mathrm{k})=1,03 \mathrm{E}-24\right)$. This study is of help to further reduce the burden of this disease and invites us all to accept the following inescapable conclusion.

\section{Conclusion}

Without a Helicobacter pylori infection no gastric cancer. Helicobacter pylori is the cause of gastric cancer.

\section{References}

Ando T., Goto Y., Maeda O., Watanabe O., Ishiguro K., \& Goto H. (2006). Causal role of Helicobacter pylori infection in gastric cancer. WJG, 12,181 .

Barukčić, K., \& Barukčić, I. (2016). Epstein Barr Virus - The Cause of Multiple Sclerosis. Journal of Applied Mathematics and Physics, 4, 1042-53. https://doi.org/10.4236/jamp.2016.46109

Barukčić, I. (1989). Die Kausalität. Hamburg: Wissenschaftsverlag, pp. 218.

Barukčić, I. (1997). Die Kausalität. Wilhelmshaven: Scientia, 1997. pp. 374.

Barukčić, I. (2005). Causality. New Statistical Methods. Hamburg - Norderstedt: Books on Demand, pp. 488.

Barukčić, I. (2006). Causality. New Statistical Methods, Second English Edition. Hamburg- Norderstedt: Books on Demand, pp. 488.

Barukčić, I. (2006). New method for calculating causal relationships. Proceeding of XXIII ${ }^{\text {rd }}$ International Biometric Conference. July 16-21; McGill University, Montréal, Québec, Canada. p. 49.

Barukčić, I. (2009). Helicobacter Pylori: The Cause of Human Gastric Cancer. In: Book of Abstracts of the 5 th Conference of the Eastern Mediterranean Region of the International Biometric Society (Istanbul: May 1014, 2009). Editor: Ergun Karaağaoğlu. Istanbul, p. 220.

Barukčić, I. (2011). Causality I. A Theory of Energy, Time and Space. Morrisville: Lulu, pp. 648.

Barukčić, I. (2011). Causality II. A Theory of Energy, Time and Space. Morrisville: Lulu, pp. 376.

Barukčić, I. (2016). The Mathematical Formula of the Causal Relationship k. International Journal of Applied Physics and Mathematics, 6, 45-65. https://doi.org/10.17706/ijapm.2016.6.2.45-65

Barukčić, I. (2016). Unified Field Theory. Journal of Applied Mathematics and Physics, 4, 1379-1438. https://doi.org/10.4236/jamp.2016.48147

Barukčić, I. (2017). Anti Bohr - Quantum Theory and Causality. International Journal of Applied Physics and Mathematics, 7, 93-111. https://doi.org/10.17706/ijapm.2017.7.2.93-111

Barukčić, I. (2017). Helicobacter pylori-The Cause of Human Gastric Cancer. Journal of Biosciences and Medicines, 5, 1-9. https://doi.org/10.4236/jbm.2017.52001

Barukčić, I. (2017). Theoriae causalitatis principia mathematica. Hamburg - Norderstedt: Books on Demand, p244. 
https://www.bod.de/buchshop/theoriae-causalitatis-principia-mathematica-ilija-barukcic-9783744815932

Barukčić, I. (2018). Epstein Bar Virus-The Cause of Hodgkin's Lymphoma. Journal of Biosciences and Medicines, 6, 75-100. https://doi.org/10.4236/jbm.2018.61008

Barukčić, I. (2018). Fusobacterium nucleatum-The Cause of Human Colorectal Cancer. Journal of Biosciences and Medicines, 6, 31-69. http://dx.doi.org/10.4236/jbm.2018.63004Cance

Barukčić, I. (2018). Human Papillomavirus-The Cause of Human Cervical Cancer. Journal of Biosciences and Medicines, 6, 106-125.

Bizzozero, G. (1893). Ueber die schlauchförmigen Drüsen des Magendarmkanals und die Beziehungen ihres Epithels zu dem Oberflächenepithel der Schleimhaut Dritte Mittheilung. Archiv f. mikrosk. Anat., 42, 82-152.

Blaser, M. J. (2005). An Endangered Species in the Stomach. Sci Am, 292, 38-45.

Buckley, M. J. M., \& O'Morain, C. A. (1998). Helicobacterbiology - discovery. British Medical Bulletin, 54, 7-16.

Buzás, G. M. (2004). A helicobacter pylori felfedzésének története. Orvostorteneti kozlemenyek, 49, 45-56.

Correa, P., \& Piazuelo, M. B. (2012). Evolutionary History of the Helicobacter pylori Genome: Implications for Gastric Carcinogenesis. Gut and Liver, 6, 21-28.

Donati, M. (1586). De medica historia mirabili libri sex. Mantuae: Per Franciscum Osanam, Cap iii, 19. Retrieved from https://archive.org/details/demedicahistoria1586dona

Estevens, J., Fidalgo, P., Tendeiro, T., Chagas, C., Ferra, A., Leitao, C. N., \& Mira, F. C. (1993). Anti-Helicobacter pylori antibodies prevalence and gastric adenocarcinoma in Portugal: report of a case-control study. European Journal of Cancer Prevention the Official Journal of the European Cancer Prevention Organisation (ECP), 2, 377-380.

Fernández de Larrea-Baz, N., Pérez-Gómez, B., Michel, A., Romero, B., Lope, V., Pawlita, M., Fernández-Villa, T., ... Aragonés, N. (2017). Helicobacter pylori serological biomarkers of gastric cancer risk in the MCCSpain case-control Study. Cancer epidemiology, 50, 76-84.

Ferro, A., Peleteiro, B., Malvezzi, M., Bosetti, C., Bertuccio, P., Levi, F., Negri, E., La Vecchia, C., \& Lunet, N. (2014). Worldwide trends in gastric cancer mortality (1980-2011), with predictions to 2015, and incidence by subtype. European Journal of Cancer (Oxford, England 1990), 50, 1330-1344.

Forman, D., Newell, D. G., Fullerton, F., Yarnell, J. W., Stacey, A. R., Wald, N., \& Sitas, F. (1991). Association between infection with Helicobacter pylori and risk of gastric cancer: Evidence from a prospective investigation. $B M J, 302,1302-1305$.

González, C. A., Megraud, F., Buissonniere, A., Lujan, B. L., Agudo, A., Duell, E. J., Boutron-Ruault, M. C., Clavel-Chapelon, F., Palli, D., Krogh, V., Mattiello, A., Tumino, R., Sacerdote, C., Quirós, J. R., ... Riboli, E. (2012). Helicobacter pylori infection assessed by ELISA and by immunoblot and noncardia gastric cancer risk in a prospective study: the Eurgast-EPIC project. Annals of Oncology Official Journal of the European Society for Medical Oncology, 23, 1320-1324.

Hanley, J. A., \& Lippman-Hand, A. (1983). If Nothing Goes Wrong, Is Everything All Right? The Journal of the American Medical Association, 249, 1743-1745. http://doi.org/10.1001/jama.1983.03330370053031

Huang, J. Q., Sridhar, S., Chen, Y., \& Hunt, R. H. (1998). Meta-analysis of the relationship between Helicobacter pylori seropositivity and gastric cancer. Gastroenterology, 114, 1169-1179.

Huerta, J. M., Chirlaque, M. D., Molina, A. J., Amiano, P., Martín V., Fernández-Villa, T., Pérez-Gómez B., Moreno V., Burgui R., Gómez-Acebo I., Ramos-Lora M., Fernández-Tardón G., Peiró R., Olmedo-Requena, R., Pollán, M., Kogevinas, M., Castaño-Vinyals, G., \& Aragonés, N. (2017). Physical activity domains and risk of gastric adenocarcinoma in the MCC-Spain case-control study. PloS One, 12, e0179731.

IARC Working Group on the Evaluation of Carcinogenic Risks to Humans. (1994). Schistosomes, liver flukes and Helicobacter pylori. Lyon, 7-14 June 1994. IARC Monographs on the Evaluation of Carcinogenic Risks to Humans, 61, 1-241.

Jovanovic, B. D., \& Levy, P. S. (1997). A Look at the Rule of Three. The American Statistician, 51, 137-139. http://doi.org/10.1080/00031305.1997.10473947

Keck, J. W., Miernyk, K. M., Bulkow, L. R., Kelly, J. J., McMahon, B. J., Sacco, F., Hennessy, T. W., \& Bruce, M. G. (2014). Helicobacter pylori Infection and Markers of Gastric Cancer Risk in Alaska Native Persons: A Retrospective Case-Control Study. Canadian Journal of Gastroenterology \& Hepatology, 28, 305-310. 
Lin, J. T., Wang, L. Y., Wang, J. T., Wang, T. H., Yang, C. S., \& Chen, C. J. (1995). A nested case-control study on the association between Helicobacter pylori infection and gastric cancer risk in a cohort of 9775 men in Taiwan. Anticancer research, 15, 603-606.

Louis, T. A. (1981). Confidence Intervals for a Binomial Parameter after Observing No Successes. The American Statistician, 35, 154. http://doi.org/10.1080/00031305.1981.10479337

Miki, K. (2011). Gastric cancer screening by combined assay for serum anti-Helicobacter pylori IgG antibody and serum pepsinogen levels - "ABC method". Proc. Jpn. Acad., Ser. B, 87, 405-414.

Moss, S. F. (2017). The Clinical Evidence Linking Helicobacter pylori to Gastric Cancer. Cellular and Molecular Gastroenterology and Hepatology, 3, 183-191.

Nomura, A., Stemmermann, G. N., Chyou, P. H., Kato, I., Perez-Perez, G. I., \& Blaser, M. J. (1991). Helicobacter pylori infection and gastric carcinoma among Japanese Americans in Hawaii. The New England Journal of Medicine, 325, 1132-1136.

Parsonnet, J., Friedman, G. D., Vandersteen, D. P., Chang, Y., Vogelman, J. H., Orentreich, N., \& Sibley, R. K. (1991). Helicobacter pylori infection and the risk of gastric carcinoma. The New England Journal of Medicine, $325,1127-1131$.

Pearson, K. (1900). On the Criterion That a Given System of Deviations from the Probable in the Case of a Correlated System of Variables Is Such That It Can Be Reasonably Supposed to Have Arisen from Random Sampling. Philosophical Magazine Series, 5, 157-175. http://dx.doi.org/10.1080/14786440009463897

Rokkas, T., Rokka, A., \& Portincasa, P. (2017). A systematic review and meta-analysis of the role of Helicobacter pylori eradication in preventing gastric cancer. Annals of Gastroenterology, 30, 414-423.

Rumke, C. L. (1975). Implications of the Statement: No Side Effects Were Observed. The New England Journal of Medicine, 292, 372-373. http://doi.org/10.1056/NEJM197502132920723

Sarker, K. K., Kabir, M. J., Bhuyian, A. K. M. M. U., Alam, M. S., Chowdhury, F. R., Ahad, M. A., Rahman, M. A., \& Rahman, M. M. (2017). H. pylori infection and gastric cancer in Bangladesh: a case-control study. International journal of surgery. Oncology, 2, e44.

Schwarz, K. (1910). Ueber penetrierende Magen- und Jejunalgeschwure. Beitrage Zur Klinischen Chirurgie, 67, 96-128.

Shuto, M., Fujioka, T., Matsunari, O., Okamoto, K., Mizukami, K., Okimoto, T., Kodama, M., ... Murakami, K. (2017). Association between Gastric Cancer Risk and Serum Helicobacter pylori Antibody Titers. Gastroenterology research and practice, 2017, 1286198.

Tobacco smoke and involuntary smoking, Vol. 83. International Agency for Research on Cancer. Lyon, France: IARC Press; 2004. IARC Monographs on the evaluation of carcinogenic risks to humans; pp. 59-94.

Uemura, N., Okamoto, S., Yamamoto, S., Matsumura, N., Yamaguchi, S., Yamakido, M., Taniyama, K., Sasaki, N., \& Schlemper, R. J. (2001). Helicobacter pylori infection and the development of gastric cancer. The New England Journal of Medicine, 345, 784-789.

Warren, J. R., \& Marshall, B. J. (1983). Unidentified curved bacilli on gastric epithelium in active chronic gastritis. The Lancet, 321, 1273-1275.

Yoshida, T., Kato, J., Inoue, I., Yoshimura, N., Deguchi, H., Mukoubayashi, C., Oka, M., Watanabe, M., ... Ichinose, M. (2014). Cancer development based on chronic active gastritis and resulting gastric atrophy as assessed by serum levels of pepsinogen and Helicobacter pylori antibody titer. International Journal of Cancer, 134, 1445-1457.

\section{Copyrights}

Copyright for this article is retained by the author(s), with first publication rights granted to the journal.

This is an open-access article distributed under the terms and conditions of the Creative Commons Attribution license (http://creativecommons.org/licenses/by/4.0/). 